\title{
O mercado de trabalho: uma perspectiva de longa duração
}

\author{
ALEXANDRE DE FREITAS BARBOSA ${ }^{I}$
}

\section{Introdução}

$\mathrm{E}$

STE ENSAIO pretende traçar um panorama histórico sobre o mundo do trabalho no Brasil. O foco é a longa duração, ressaltando a partir de alguns cortes temporais as principais transformações e a dialética entre ruptura e continuidade presente em cada período. Sob esse prisma, acreditamos ser possível articular uma narrativa sobre o trabalho no Brasil cobrindo o longo período que vai da colônia ao final do processo de industrialização.

Os períodos abarcados são os seguintes: 1 Colônia e não mercado de trabalho; 2 Construção do mercado de trabalho no Brasil (1850-1930); 3 Nacionalização e consolidação do mercado de trabalho (1930 a 1980). Esses períodos que orientam a análise - e, portanto, conformam a estrutura do ensaio - também compreendem mudanças estruturais internas, além de se apresentarem sob conformações distintas nos vários espaços do território nacional.

Para além do esforço de periodização e da perspectiva histórico-estrutural, procuramos apontar, ainda que de forma esquemática, quem eram os trabalhadores brasileiros "representativos" de cada período, mas sem colocar em xeque a complexidade do universo social.

É nosso objetivo também apontar as (im)possibilidades dinâmicas do nosso desenvolvimento a partir do mundo do trabalho, assim como os seus impactos em termos da estrutura social.

Assumimos, portanto, que as características do "mercado de trabalho" permitem revelar os segredos internos dos vários "padrões de desenvolvimento" no país, os quais não se sucedem de maneira linear, mas carregam as contradições dos períodos anteriores processadas num novo patamar. Tal premissa não sugere qualquer teleologia implícita, haja vista que o nosso enfoque prioriza não apenas as rupturas, mas também as continuidades.

É importante ressaltar que ao assumir a categoria "mercado de trabalho" como estruturante, procuramos fugir ao anacronismo que incorrem vários historiadores e estudiosos, especialmente os da colônia e do Império. Muitos autores referem-se a "desempregados" e "assalariados" num momento em que o mercado de trabalho ainda não tinha sequer suas possibilidades virtuais estabele- 
cidas. Nesse sentido, adoção da categoria mercado de trabalho implica o uso de todo o seu potencial analítico e conceitual, inclusive para os momentos em que ele não permeava a realidade social.

Finalmente, o esforço aqui empreendido significa um alargamento do horizonte histórico e um desenvolvimento das premissas contidas na nossa tese de doutorado sobre a formação do mercado de trabalho no Brasil, defendida em 2003, e publicada cinco anos depois (Barbosa, 2008). Tal empreendimento é, em muito, devedor das reflexões realizadas em sala de aula, junto com os alunos, no âmbito da disciplina de graduação "História Econômica do Trabalho no Brasil", ministrada no IEB/USP, desde 2010.

\section{O não mercado de trabalho: escravos e agregados na colônia}

Abordar a dinâmica do mundo do trabalho no longo período abarcado pela colônia é um desafio. Existem particularidades de monta que avultam à medida que nos aproximamos do século XIX, especialmente se lançamos a vista para os vários espaços dessa formação econômica e social específica.

Ainda assim, podemos adentrar, em linhas gerais, a estrutura dessa economia - que eram várias, mas sempre girando em torno das atividades que emprestavam o sentido da colonização - e dessa sociedade escravista peculiar.

Marx e Weber nos fornecem algumas pistas para desvendar o particular da nossa formação histórica em face da experiência “universal”, caracterizada pela expansão do capitalismo.

Para Marx (1991, p.110), "se falarmos dos proprietários das plantations na América como capitalistas, e que sejam capitalistas, isto se baseará no fato deles existirem como anomalias em um mercado mundial baseado no trabalho livre".

A concepção de Weber (2001, p.85) sobre a escravidão moderna nas Américas está explicitada no seguinte trecho:

[...] a escravidão é apenas rentável quando se executa com estrita disciplina e vem associada a uma exploração implacável; outros requisitos são a possibilidade de encontrar escravos e alimentá-los a baixo preço, e de desenvolver um cultivo predatório extensivo, que requer por sua vez disponibilidades ilimitadas de terra.

Apesar dos seus postulados teóricos distintos, esses autores nos permitem revelar a peculiaridade da colônia, podendo ser vistos como complementares. No caso de Marx, a "anomalia" colonial significa que a imprópria caracterização dos proprietários de terras e escravos como "capitalistas" - já que as relações de produção não o são - advém da existência de um mercado mundial onde o capitalismo se expande com novas relações de produção. Weber revela, por sua vez, as condições que permitem essa anomalia: coerção não econômica e disponibilidade de terras e escravos a baixo preço.

Podemos, assim, sugerir a existência de um "não-mercado de trabalho" (Barbosa, 2008) durante o período colonial. Por que o "não" seguido de hífen? 
Ora, pelo fato de que os trabalhadores eram assegurados pelo tráfico de escravos. Portanto, esses não passavam pelo mercado de trabalho, inexistente, na medida em que não haviam se separado das condições objetivas de produção e reprodução.

Seguindo a formulação marxista, como não eram expropriados, não podiam vender a sua força de trabalho. Não se trata de uma diferenciação meramente jurídica. A característica essencial das formações econômicas e sociais capitalistas é que elas criam não apenas um mercado interno pela "destruição de todos os ofícios subsidiários rurais", como ressalta Marx, mas também em virtude de possibilidades expansivas próprias oriundas da acumulação de capital viabilizada pela redução dos custos do trabalho em virtude dos ganhos de produtividade. Não havia, pois, acumulação endógena de capital na colônia, mas tão somente esterilização de capital sob a forma do escravo.

Quando olhamos para as atividades nucleares da colônia - açúcar, ouro, algodão etc. -, o que salta aos olhos é a predominância do trabalho escravo. Se agricultura exportadora foi o "nervo econômico da colonização" - tendo sido a mineração "uma transição para o aniquilamento" e a atividade extrativa se caracterizado por não ter a propriedade territorial por base -, ela teria contado com a disponibilidade de trabalho escravo para o seu sucesso comercial. A concentração de escravos e terras condicionaria a organização da produção, engendrando uma estrutura social peculiar. Os demais setores de atividade - agricultura de subsistência, pecuária, indústria - seriam acessórios e subsidiários em relação àquilo que conferia o "sentido da colonização" (Prado Jr., 1942, p.113-18).

Para Caio Prado Jr. (1942, p.279-80, 283-7, 341), no setor orgânico, o trabalho escravo seria predominante, enquanto nos ramos acessórios predominariam várias formas de "trabalho livre" e, em alguns casos, inclusive o trabalho escravo se faria presente. Nesse sentido, o escravo estaria inserido na ordem social, enquanto os "homens livres pobres" conformariam, em grande medida, os "desclassificados sociais", ao menos do ponto de vista da estrutura da economia exportadora. Compunham "um imenso setor inorgânico de populações desenraizadas", cujo vulto cresce à medida que, por conta da "evolução por arrancos, pedaços da estrutura colonial se desfaziam". Os homens livres pobres, concentrados no campo, possuíam apenas "liberdade relativa", a "de mudar de um senhor para o outro", como no caso dos agregados roceiros ou dos vendeiros e tropeiros.

O esquema analítico de Caio Prado Jr. permite adentrar a estrutura social da colônia. Serve como ponto de partida. Em vez de encerrar o debate, ele fornece a chave para a compreensão das várias formas de trabalho escravo e "livre".

No caso do setor orgânico, por exemplo, havia "múltiplas formas de condição escrava". Um escravo do eito era diferente de um escravo da casa grande, ou do escravo mineiro, do tropeiro, do negro de ganho, e assim por diante. "Um crioulo valia quatro vezes um boçal", conforme se dizia no período colo- 
nial. E havia escravos especializados, artesãos, no campo e nas cidades, submetidos a várias formas de coação e de "remuneração". Segundo Kátia Mattoso (1990, p.11, 99-101, 107-10), não havia uma, mas várias relações de produção escravistas. Não conformavam os escravos, portanto, uma classe social completa, nem "em si", nem "para si". O que tinham em comum era o fato de desempenharem "funções e tarefas das quais dependia a classe dominante".

A sociedade escravista brasileira pode ser descrita, segundo Mattoso (1990, p.11), como "um corpo social de dupla estrutura". E era escravista não apenas em virtude da presença absorvente e predominante do trabalho escravo, mas pelo fato de que as distinções sociais se davam de acordo com o estoque de escravos que possuíam os brancos diretores da empresa colonial. Não à toa, o mais próximo da figura do camponês eram os pequenos agricultores, eles mesmos donos de escravos (Schwartz, 1995, p.209-10, 218-19). Os demais seriam párias vegetando à sombra de algum "coronel”, justamente por não terem escravos. Adicionalmente, uma sutil hierarquia social seria traçada entre os escravos, por meio da mestiçagem, estabelecendo clivagens internas a esse grupo.

Nesse sentido, para Luiz Felipe Alencastro (2000, p.346-53), apenas na colônia produtora escravista, diretamente vinculada à economia-mundo, e não na colônia reprodutora de escravos na África, seria possível montar uma sociedade plurirracial. A miscigenação seria o resultado demográfico de uma relação de dominação que exigia a organização da produção e inclusive a realização de tarefas com alguma qualificação tanto nos engenhos como nas cidades.

Por sua vez, a expansão da escravidão com mão de obra africana permite integrar o indígena, o escravo da terra, como mão de obra complementar, especialmente depois que o gado, no século XVIII, avança para o interior e o expulsa de suas terras (Alencastro, 2000, p.339-40). Já o negro forro ou liberto, além de carregar a pecha da escravidão, é muitas vezes relegado à condição de pária, de desclassificado social.

A participação dos libertos na vida nacional, apesar de traço relevante durante a colônia, adquire vulto no século XIX. Segundo Hasenbalg (2005, p.143$4,147-8$ ), a população de cor livre salta de $13 \%$ para $43 \%$ da população vivendo no território brasileiro entre 1798 e 1872, o que se explica pela combinação entre alforrias (gratuitas, onerosas ou sob condição), miscigenação e crescimento vegetativo, que não era negativo como no caso da população escrava.

Mas como e em que atividades se inseriam os negros libertos? Tudo indica que disputavam os espaços existentes na estrutura social, em lento processo de transformação, com os brancos livres pobres, mas também com os escravos, especialmente nas "cidades negras" da primeira metade do século XIX.

Eram elas Rio de Janeiro, Recife, Salvador, São Luís, Belém e Porto Alegre, pois abrigavam uma miríade de atividades urbanas em espaços que estabeleciam a gestão comercial e dos negócios públicos das áreas circundantes. Esse período por sua vez antecede o momento em que os escravos passam a se concentrar 
exclusivamente no campo, ou seja, nas atividades mais rentáveis, em decorrência da elevação do seu preço após 1850, quando tem lugar o tráfico inter-regional.

Vale dizer inicialmente que, nas áreas rurais, essa camada de "mestiços desraçados" era inserida nas funções não desempenhadas pelo escravo, tais como policiamento, desmatamento, preparo do solo e supervisão. Eram caracterizadas pelo imediatismo, pela instabilidade e pela itinerância, ocupando os interstícios deixados pelo trabalho escravo. Mas nem por isso deixavam de ser "úteis" à empresa colonizadora, quando mais não fosse para manter "ocupada" essa mão de obra expropriada, como ressalta Laura de Mello e Souza (2004, p.91, 96, 106-7) no seu estudo sobre Minas Gerais durante e após a aventura mineradora.

Nas áreas urbanas, predominavam os negros de ganho no comércio, no amplo setor de serviços, mas também na atividade industrial. A sua remuneração poderia ser totalmente revertida ao senhor que deveria lhes assegurar manutenção, ou então esses trabalhadores ficariam encarregados de pagar uma quantia fixa, "a semana", aos seus proprietários. Em alguns casos, esses escravos possuíam maior "liberdade" de locomoção e até de residência. Mas seria um exagero dizer que fossem menos coagidos que os demais escravos. A diferença é que os espaços de sociabilidade urbanos permitiam, em tese, o preenchimento de novas posições sociais, pelo fato de já atuarem no âmbito de uma economia monetária, como no caso dos carregadores, alfaiates, ambulantes, quitandeiras e amas de leite.

O historiador Luiz Cláudio Soares (2007, p.40-59) traça um panorama da estrutura do mercado de escravos na capital do Império, depois de 1831, ano em que foi fechado o Mercado do Valongo. Proliferaram então escritórios ou casas de compra, venda ou aluguel de escravos. Quando eram alugados, cobrava-se uma taxa do proprietário, tal como num mercado imobiliário. Muitos rentistas viviam do aluguel de alguns poucos escravos, os quais por vezes haviam sido qualificados para a realização de um ofício, o que elevava o seu preço. No Rio de Janeiro, os serviços domésticos, as diversas modalidades de ganho na rua e as atividades industriais (inclusive as pequenas oficinas e artesãos) eram as mais demandantes de escravos na primeira metade do século XIX. Até a Câmara Municipal da Corte alugava escravos em troca do pagamento de um "salário mensal" aos seus proprietários.

Outro ponto digno de nota é a concorrência entre os livres e libertos, especialmente antes de 1850 , já que depois o trabalho escravo nas cidades transforma-se em "luxo". É importante ressaltar que não havia nem desocupados e nem assalariados regulares como conhecemos hoje, pois sequer mercado de trabalho existia. Os assalariados existentes recebiam inclusive um valor correspondente ao obtido com o aluguel dos escravos de acordo com seus ofícios.

Manuela Carneiro da Cunha (2012, p.82-6, 102-26) ressalta que a preferência pelo cativo se dava pelo fato de ele significar "segurança", dada a fluidez da inserção dos libertos no mundo do trabalho. Mas crescentemente, num contexto de abundância de libertos, o escravo passa a ser excluído de várias 
ocupações, especialmente as marítimas e as mecânicas, inclusive por meio da imposição de taxas discriminatórias por parte do poder público. Já a agricultura, as artes grosseiras e os serviços domésticos continuam se afirmando enquanto espaços privilegiados da escravidão. Em última instância, o que distinguia os escravos dos libertos era "ser ou não ser capital investido".

Aos poucos, portanto, nas cidades negras do Brasil oitocentista - mas não na São Paulo do final do século, onde os imigrantes davam a tônica -, os libertos vão ocupando os espaços dos antigos "negros de ganho" num vasto setor de serviços e comércio urbanos. Esses trabalhadores ainda não submetidos ao assalariamento perfaziam atividades como "autônomos" de todo o tipo, prestando serviços eventuais a um ou mais senhores.

Não se tratava tampouco de prenúncio de "setor informal", haja vista que esse tem a sua dinâmica derivada dos espaços deixados pelo "setor formal" e capitalista, então ainda inexistente. A acumulação de capital não havia se internalizado, sequer nas atividades agrícolas. A existência das atividades urbanas dependia da riqueza nelas gerada, onde ainda predominava o trabalho escravo. $\mathrm{O}$ mercado de trabalho urbano era inexistente, havendo algumas raras posições assalariadas quase que sitiadas por um mar de serviçais com remuneração baixa e incerta.

\section{A lenta transição: do fim do tráfico aos mercados regionais e incompletos (1850 a 1930)}

$\mathrm{O}$ mercado de trabalho não nasceu de chofre no Brasil. Foi um longo parto. A Abolição não significou a emergência do trabalho assalariado. Deu lugar a várias formas de trabalho não escravo. Na exímia síntese de Caio Prado Jr. (1985, p.202), gerou "um tipo de relações que sem serem servis, conservarão traços acentuados do regime abolido". E, como veremos, com diferenças marcantes nos vários espaços do território.

Nesse sentido, discordamos da afirmação de Luiz Felipe Alencastro (2000) que encerra o seu clássico sobre a escravidão e o tráfico de escravos no Brasil. Discordância conceitual, mas importante para se compreender o longo momento de transição que vai de 1850 a 1930 . Afirma o historiador que, de 1550 a 1930, o "mercado de trabalho está desterritorializado", referindo-se à mão de obra africana, e depois imigrante, que "nasce e cresce fora do território colonial e nacional" (Alencastro, 2000, p.354). Ora, em primeiro lugar, não havia - e nem se pode conceber - mercado de trabalho numa formação social escravista. Segundo, parte expressiva da força de trabalho recrutada no período pós-Abolição, com a exceção do oeste cafeeiro e da cidade de São Paulo, era composta pelo "elemento nacional".

O período em tese compreende, em alguma medida, o que Florestan Fernandes (1987, p.224-7) descreve como a "fase de eclosão do mercado capitalista especificamente moderno". Existe mercado capitalista, mas não um sistema de acumulação capitalista, ao menos não para o conjunto do Brasil. 
O fim do isolamento da grande lavoura por meio do seu intercruzamento com a economia urbana em expansão, no período pós-Independência, gerava, portanto, uma reorganização nos fluxos internos de renda, o que será, de fato, acelerado no último quarto do século XIX. Mas isso não foi suficiente para que o capitalismo "nascesse" ou "crescesse" a partir da diferenciação interna do sistema colonial. O "setor velho" não se destruiu para gerar o "setor novo", conforme as palavras do sociólogo paulista (Fernandes, 1987, p.79-81).

De fato, o que encontramos é a utilização de várias relações não capitalistas de modo a assegurar a expansão da agricultura de exportação ou da extração vegetal no caso da borracha amazônica. Mas cada relação social de produção combinava-se de maneira específica com o cenário externo (mais ou menos dinâmico) e as potencialidades de acumulação internas, além de estar vinculada às políticas migratórias ou de utilização da mão de obra nacional. Assim, as diversas formas de encaminhamento da substituição do trabalho escravo pelo "livre" geraram uma "ruptura do equilíbrio regional no Brasil" durante a segunda metade do século XIX (Mello, 1999, p.68).

Apenas na cidade de São Paulo, verifica-se a emergência do primeiro núcleo de mercado de trabalho urbano e regional não abortado, o qual depois se disseminaria de forma seletiva para o restante do país. Até 1930, portanto, teremos quando muito mercados de trabalho fragmentados, porque regionais, $\mathrm{e}$ sem fluxos migratórios expressivos; e incompletos, pela preponderância do não assalariamento.

Antes, porém, de acompanharmos a nova configuração espacial das relações de trabalho durante o período 1850-1930, é importante ressaltar que essas não surgiram ao acaso, pois eram oriundas de um conjunto de leis e ações formuladas pelo Estado no Brasil Império, cujo principal objetivo era defender os interesses dos novos (velhos) quase-empregadores do centro dinâmico e dos subempregadores nas demais regiões do país, num contexto de crescente escassez do trabalho escravo.

O ano 1850 marca uma ruptura na história econômica e social do Brasil. Com a proibição efetiva do tráfico de escravos, o principal fator de produção (que era ao mesmo tempo fonte de capital e de trabalho) tornava-se escasso, configurando uma nova situação que Furtado $(1959$, p.141) chamaria de "inelasticidade da oferta de trabalho".

Isso significa que, caso a produção aumentasse, não haveria mão de obra na quantidade necessária e a preços baixos. Os escravos excedentes do "Norte" poderiam ser remanejados para o Centro-Sul em certa medida, expediente bastante utilizado. Também se tentou fazer uso do "contrato de parceria", algo que tornava os imigrantes europeus responsáveis pelo custeio do seu transporte e, portanto, endividados e "imóveis".

No mesmo ano, seria aprovada a Lei de Terras, a qual não se entende sem o fim do tráfico. O objetivo era assegurar a ocupação das terras pelos latifun- 
diários. Se a posse e a doação estavam agora proibidas, a aplicação da lei - sem a demarcação das terras e o pagamento dos impostos correspondentes - dava livre acesso às terras públicas a quem pudesse ocupá-las por meio da compra de falsos títulos de propriedade. O intuito era impedir a produção das condições de subsistência para os segmentos sociais passando por processos de expropriação.

As leis de desescravização (do Ventre Livre - 1871; e dos Sexagenários 1885), apesar da resistência de vários proprietários de terras, cada vez mais concentrados no Centro-Sul do país, cumpriam dois objetivos básicos: postergar ao máximo o fim do trabalho escravo, por meio da criação da figura do "ingênuo"; e criar mecanismos de disciplinamento dos trabalhadores não escravos (Barbosa, 2008, p.93, 116-17).

Com a lei do Ventre Livre, o Estado passa a atuar de forma decisiva nas relações entre "a casa grande" e a "senzala". Ficava assegurado não só o pecúlio ao trabalhador escravo, como também o direito de comprar a sua alforria depositando o valor em juízo, em caso de não anuência do proprietário, para o que se montava um tribunal com os árbitros (todos eles homens livres) das partes.

Com o primeiro Recenseamento Geral da População, foi contabilizado o total de escravos no Brasil ( 1,5 milhão), e estabelecidos os critérios para os escravos a serem liberados por meio do Fundo Nacional de Emancipação.

O objetivo da lei era fazer que os ingênuos - que deveriam ficar nas fazendas até completarem 21 anos de idade - depois se transformassem em trabalhadores "livres". Assim estendia-se no tempo o controle sobre a força de trabalho escrava. Não apenas: os escravos libertados ficariam cinco anos sob inspeção do governo. No caso de "viverem como vadios", seriam constrangidos a trabalhar nos estabelecimentos públicos. A coerção revela que o mercado de trabalho, ainda inexistente, precisava operar na marra. Portanto, a legislação não cuidava apenas dos ingênuos, mas de todos os escravos e libertos.

Da mesma forma, a Lei dos Sexagenários cuidava menos dos trabalhadores escravos com mais de 65 anos - o que era raro na época - sumariamente libertados, e mais aos preços dos demais escravos a serem alvos de alforrias, estabelecidos acima da taxa de mercado. Acordos de prestação de serviços para aqueles proprietários que liberassem seus escravos também foram estipulados. Os libertos não poderiam trocar de município pelo período de cinco anos. Com essa lei, também fica proibido o tráfico inter-regional de escravos.

Para os trabalhadores imigrantes, a legislação em voga data de 1837 . O seu objetivo era "atar" o "trabalhador livre" ao locatário da sua força de trabalho. Previa-se a indenização ao contratante no caso de demissão com justa causa, facilmente "fabricada", pois abarcava os casos de doença, embriaguez, injúria e imperícia. Caso o trabalhador não dispusesse de recursos, ele seria condenado a trabalhar em obras públicas ou seria recolhido à prisão.

Nesse sentido, a Lei de Locação de Serviços, assinada em 1879, procurava fornecer mais incentivos aos trabalhadores imigrantes numa situação de escassez 
de braços para a lavoura. A pena de prisão seria reduzida, e as "greves" punidas severamente. Mas a dívida com o transporte passível de ser cobrada não poderia superar os $50 \%$ dos gastos.

Os contratos seriam assinados por trabalhadores maiores de 21 anos, tendo duração máxima de cinco anos para os estrangeiros, de seis anos para os trabalhadores nacionais livres e de sete anos para os libertos, conforme estipulado na Lei de 1871. Os trabalhadores urbanos ficariam regidos pelo Código Comercial. Os escravos remanescentes estariam sob a alçada das legislações de 1871 e 1885.

Esse ordenamento jurídico abarcava todos os segmentos de trabalhadores. Mas a sua aplicação seria desnecessária. No caso dos imigrantes, onde eram mais necessitados, a província de São Paulo, já em 1884, e com aporte adicional de recursos por parte do governo imperial, asseguraria os custos de transporte e, portanto, a sua livre mobilidade. Na região dinâmica, agora que a oferta de trabalho se fazia elástica, a Lei de 1879 mostrava-se desnecessária, sendo revogada em 1890. Já nos demais espaços do país, o excedente de mão de obra potencial assegurava a sua inclusão nas fazendas num regime assemelhado à escravidão. A regulação do trabalho ficaria a cargo dos subempregadores por meio da combinação de força e favor.

A "liberdade do trabalho", instaurada pela Constituição Republicana, estipulava que o Estado não poderia intervir nas relações de trabalho. Isso apenas mudaria, em 1926, com a emenda constitucional de número 29, que facultava ao Congresso o direito de legislar sobre a questão do trabalho, o que traria poucos impactos efetivos. Mesmo com a aprovação de legislação sindical para o campo, em 1903, e para as cidades, em 1907, os direitos não eram respeitados, e os trabalhadores sentiam a mão pesada do Estado atuando em benefício dos empregadores de todos os tipos. Uma combinação de força com favor permeou as velhas relações de trabalho recicladas.

O mosaico das relações de trabalho nos vários espaços regionais pode ser acompanhado a partir do "Sudeste dinâmico" num extremo, e da Amazônia da borracha no outro extremo; passando pelas experiências do Sul do país, do "Sudeste estagnado" e do Nordeste. Em cada um desses casos, a interação entre territorialização da força de trabalho e assalariamento aparece repleta de particularidades. O caso da cidade de São Paulo é um ponto fora da curva (Barbosa, 2008, p.141-60, 200-39).

No Sudeste dinâmico, basicamente nas áreas rurais do oeste paulista, o colonato foi a forma social específica encontrada. Predominava aqui uma espécie de quase-assalariamento, pois a parcela monetária recebida pelos trabalhadores era mais importante do que no resto do país. Os colonos eram quase-operários rurais travestidos de camponeses, pois podiam vender os alimentos que produziam e também consumiam. Em troca de um pedaço de terra, aceitavam menores salários. Recebiam mais pela colheita do que pelo trato do café, ou seja, não de acordo com o uso da sua força de trabalho, mas com o seu rendimento. A expan- 
são do processo de acumulação de capital, mesmo utilizando-se de formas não capitalistas, levava a um mercado interno em profundidade, em virtude da monetização do rendimento dos que trabalhavam na atividade principal ou na roça.

O oposto era o cenário verificado na região amazônica, quando a transferência da mão de obra nordestina geraria uma massa de proletários sem adjetivos, endividados no barracão e desprovidos de lotes de subsistência, tendo que perfazer jornadas de trabalho extenuantes. Aqui o regime de servidão predominava, experimentando os seringueiros "um isolamento que talvez nenhum outro sistema econômico haja imposto ao homem" (Furtado, 1959, p.160).

Num extremo, o mercado de trabalho já aparecia por meio da mobilidade do trabalhador. Havia desterritorialização com quase-assalariamento. No outro extremo, o não mercado de trabalho, à semelhança do período colonial, era a regra. Desterritorialização com situação próxima à servidão.

No Sudeste estagnado, marcado pela experiência do vale do Paraíba paulista e fluminense e da zona da mata mineira, os proprietários ficaram atados aos seus ex-escravos, já que em virtude de suas fazendas descapitalizadas não conseguiram atrair imigrantes. Como a fronteira não estava em expansão, a mão de obra nacional - composta de ex-escravos e agregados - foi incorporada por meio da meação. No Nordeste, várias situações predominaram. Mas na região açucareira surgiram os "moradores de condição". Esses trocavam um pedaço de terra pelo compromisso de trabalhar como subassalariados para os grandes proprietários. Em ambos os casos, a territorialização seria assegurada, mas o assalariamento existia quando muito sob a forma de um tênue véu monetário.

A região Sul conforma um caso à parte. Havia, de um lado, os charqueadores escravistas. De outro, os colonos pequenos proprietários de terras. As relações capitalistas seriam moldadas aos poucos por meio da conexão comercial dos núcleos coloniais, que expropriou paulatinamente seus membros, transformados em operários no campo e nas cidades. Aqui a territorialização da mão de obra se faria de forma paulatina com a expansão do assalariamento.

Seria apenas com o vulto da expansão industrial paulistana, nas duas primeiras décadas do século XX, que se destacariam a silhuetas do patrão e a do trabalhador assalariado, estruturando-se um mercado de trabalho peculiar, pois alicerçado num processo de acumulação de capital minimamente endógeno, algo que não se verificava sequer no Distrito Federal, onde as atividades industriais se resumiam ao atendimento da demanda gerada pelo setor público e pelo capital comercial.

Mas se o setor dinâmico urbano recrutava assalariados e trabalhadores autônomos sob encomenda (este era o caso dos trabalhadores da construção civil), a outra metade da força de trabalho transitava da inatividade para a precariedade (prestação de serviços de todos os tipos) e para o assalariamento eventual em pequenos estabelecimentos. Mas esses segmentos não eram estanques. Havia um trânsito elevado de trabalhadores entre esses dois tipos de atividades, o que indica a existência de um mercado de trabalho ainda sem forma e contornos definidos. 
Partindo dos dados do Censo de 1920, observamos, na Tabela 1, que a cidade de São Paulo, primeiro núcleo não abortado de mercado de trabalho no país, já contava com uma taxa de assalariamento (em relação ao total de ocupados) de $40 \%$, contra $8 \%$ para a média do país (Tabela 1 ). No que se refere apenas aos operários assalariados da indústria, São Paulo e Distrito Federal concentravam $40 \%$ desse segmento social no país.

Em outros quesitos, a participação de São Paulo era mais elevada. É o caso da população sem trabalho, $15,2 \%$ da PEA, contra $4,4 \%$ para o país, já que nas demais áreas o "desemprego" assumia a forma de uma inatividade disfarçada. A Tabela 1 revela ainda que no Brasil $70 \%$ dos ocupados estavam vinculados a atividades agrícolas e apenas 13\%, à "indústria”, então composta por poucas grandes fábricas, estando boa parte dos trabalhadores inseridos nas oficinas de caráter essencialmente artesanal.

Tabela 1 - Indicadores do mercado de trabalho - Município de São Paulo e Brasil, 1920 (Números absolutos e \% São Paulo/Brasil)

\begin{tabular}{l|c|c|c}
\hline & São Paulo & Brasil & $\begin{array}{c}\text { SP/Brasil } \\
\text { (em \%) }\end{array}$ \\
\hline População Total & 577.621 & 30.635 .605 & 1,9 \\
PIA & 390.184 & 18.004 .030 & 2,2 \\
PEA & 240.044 & 9.566 .822 & 2,5 \\
Inativos & 150.140 & 8.437 .208 & 1,8 \\
Ocupados & 203.558 & 9.150 .254 & 2,2 \\
Agricultura & 14.494 & 6.451 .530 & 0,2 \\
Serviços & 88.689 & 1.509 .367 & 5,9 \\
Indústria + Artesanato & 100.375 & 1.189 .357 & 8,4 \\
Operários Assalariados (OA) & 54.935 & 275.512 & 19,9 \\
Assalariados Total & 81.555 & 733.044 & 11,1 \\
Artesãos & 45.440 & 913.845 & 5,0 \\
População Sem Trabalho (PST) & 36.486 & 416.568 & 8,8 \\
\hline Tx Participação & 61,5 & 53,1 & \\
Tx População Sem Trabalho & 15,2 & 4,4 & \\
Razão PST/AO & 0,7 & 1,5 & \\
Operários Assalariados/Ocupados & 27,0 & 3,0 & \\
Taxa Total de Assalariamento & 40,1 & 8,0 & \\
\hline Ocupados & 100,0 & 100,0 & \\
Agricultura & 7,1 & 70,5 & \\
Serviços & 43,6 & 16,5 & \\
Indústria + Artesanato & 49,3 & 13,0 & \\
\hline
\end{tabular}

Fonte: Recenseamento Geral de 1920. Elaboração do autor. 
A síntese de Rangel (1957, p.56) capta bem o que passava longe de São Paulo e do Distrito Federal: "a economia de mercado não passa de leve crosta boiando em imenso oceano de força de trabalho". O país que havia enfrentado a inelasticidade da oferta de trabalho no século XIX parecia a ponto de superar esse desafio. Por volta dos anos 1920, o excedente estrutural de força de trabalho predominava nas cidades, enquanto no campo um terço da população em idade ativa ou se encontrava na inatividade dissimulada ou como mão de obra cujo pleno potencial não era utilizado. Iriam se desgarrar para inundar o mercado de trabalho tendencialmente nacional nos anos seguintes. Havia muita lenha para queimar nas caldeiras do capitalismo prestes a conquistar o território nacional.

Segundo Darcy Ribeiro (1995, p.26, 176-7, 233, 260-1), essa "humanidade detritária", predominantemente negra e mulata, formada durante a colônia e, apenas parcialmente, expropriada durante o processo de transição de 1850 a 1930, é oriunda da constrição gerada pelo regime de trabalho e pela concentração da propriedade fundiária. Oscilando entre as atividades de subsistência, em que não tem a posse da terra, e as atividades acumulativas, em que atua como força de trabalho bruta, vai emergindo um "Brasil-povo" e um "criatório de gente" que nessa quadra histórica, segundo nosso enfoque, aparece como uma imensa superpopulação relativa, não criada e tampouco utilizada pelo capital, ainda dispersa pelos quatro cantos do país.

\section{"Nacionalização" e consolidação do mercado de trabalho (1930 a 1980)}

A industrialização, a criação da carteira de trabalho e da CLT, junto com as migrações regionais, vão criar as condições para a nacionalização do mercado de trabalho brasileiro. Tanto do lado da demanda (novos empregos) como do lado da oferta de trabalho (para além do crescimento demográfico, uma força de trabalho latente se desprende das relações pré-capitalistas no campo), está montado o cenário para desenvolvimento do capitalismo, utilizando agora mão de obra recrutada internamente, e num montante que excede as suas necessidades imediatas.

A condição operária - marcada pela relação capital/trabalho, pela disciplina na "fábrica" e por uma consciência de classe emergente - vai se afigurar como o traço dinâmico da cena nacional. Entre 1940 e 1980, observa-se a expansão de uma classe trabalhadora assalariada, concentrada nos centros urbanos, irradiando-se de maneira seletiva a partir de São Paulo e do Sudeste em direção ao Sul, para chegar ao Norte e ao Nordeste nos anos 1960 e 1970. Além do salário mínimo, ao menos para as ocupações industriais e algumas do setor de serviços, há também o acesso ao sindicato e a um pacote de direitos sociais e trabalhistas (incluindo saúde, previdência e, por vezes, moradia).

A realização do capital passa a se dar no mercado interno. Novos setores industriais surgem, gerando encadeamentos entre si, ao passo que os serviços 
produtivos (transportes e telecomunicações), sociais e de administração pública também se expandem. Surgem assalariados por todos os lados. Mas não apenas. A dinâmica do segmento capitalista (setor formal) abre novas possibilidades para os serviços privados de baixa produtividade que compõem o segmento não capitalista (setor informal), que não atua apenas como reservatório do excedente de força de trabalho.

Quatro características marcam esse período de "nacionalização" do mercado de trabalho que "coincide" com o desenvolvimento a todo o vapor do capitalismo brasileiro. Em primeiro lugar, antes de ressaltar a expansão quantitativa e diferenciação qualitativa do mercado de trabalho, é importante apontar para a situação ao início do processo.

Em 1940, os assalariados do setor privado já representavam o principal segmento da força de trabalho (Gráfico 1), com 37\% da população economicamente ativa (PEA) e $19 \%$ da população em idade ativa (PIA), contando com um contingente de 5,5 milhões de trabalhadores. A maioria provavelmente não possuía carteira de trabalho assinada, especialmente se levarmos em consideração que a CLT sequer havia se condensado enquanto corpo jurídico a regular as relações capital/trabalho. O segmento dos trabalhadores autônomos e familiares somados representava $51 \%$ e $26 \%$ da PEA e da PIA, respectivamente. Os domésticos remunerados, $4,3 \%$, percentual acima dos funcionários públicos e profissionais liberais somados, com $4,1 \%$. O desemprego era praticamente inexistente, em virtude do assalariamento restrito, especialmente fora das metrópoles. Mais importante ainda, o total de inativos chegava a 14,2 milhões de pessoas, a maior parte das quais situadas nas áreas rurais, que passariam por um processo de expropriação no campo e/ou de atração para os centros urbanos. Esse era combustível a ser "queimado" pelo processo de acumulação de capital, drenando uma massa populacional para realizar o trabalho nas fábricas e na construção da infraestrutura urbana e de serviços públicos, além dos serviços pessoais de toda ordem.

O crescimento da oferta de trabalho pode ser acompanhado pelas curvas referentes à PEA agrícola e não agrícola. No primeiro caso, partindo de um universo pouco inferior a 10 milhões de trabalhadores em 1940, ela se estabiliza, entre 1960 e 1980, com um contingente de 12,5 milhões de pessoas. O crescimento impressionante fica a cargo da PEA não agrícola que salta de 5 milhões para 30 milhões de trabalhadores entre 1940 e 1980 (Gráfico 2). Uma expansão anual de 4,6\%, puxada pelo dinamismo do emprego nas áreas urbanas, tanto nas regiões mais industrializadas como nas demais, gerando diferentes estruturas ocupacionais no espaço.

Vale ressaltar que durante todo esse período as taxas de desemprego se mostram relativamente baixas. Em poucas palavras, as comportas se abriam e a força de trabalho rural não plenamente utilizada inundava as áreas urbanas em busca de emprego. 


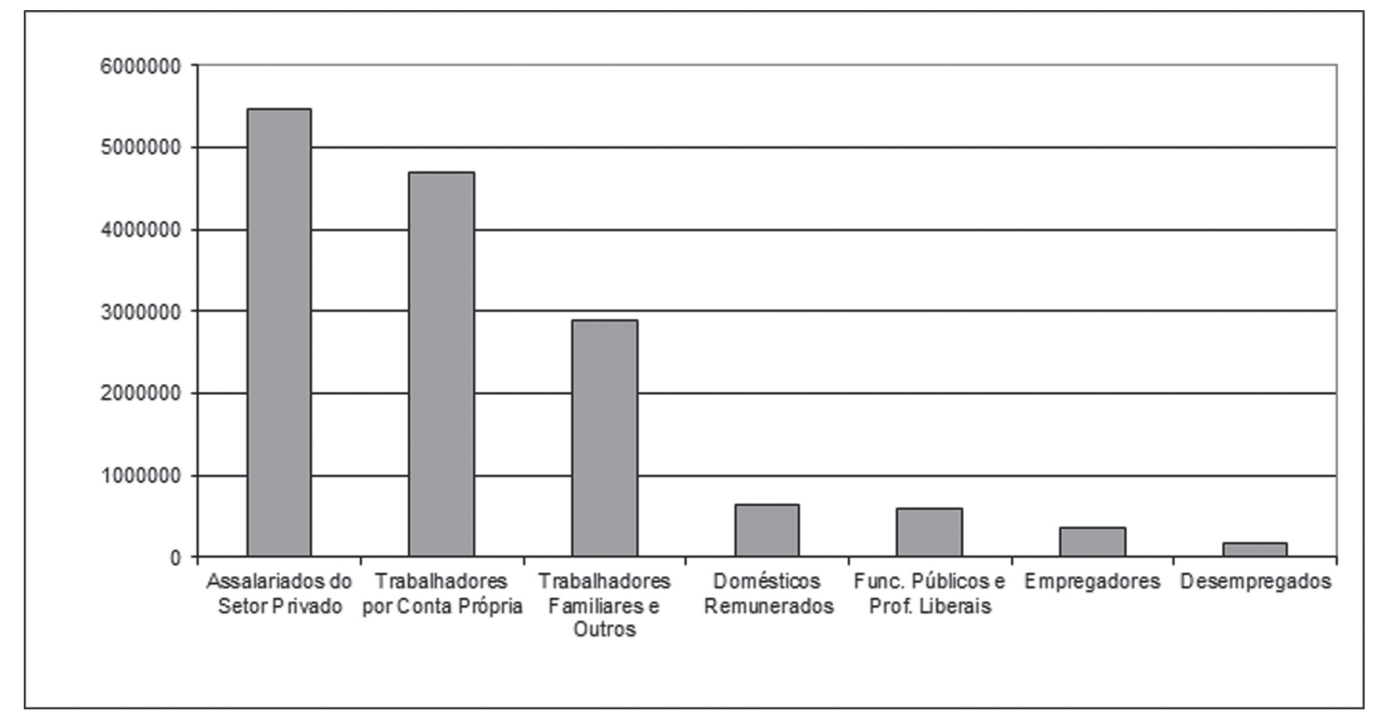

Fonte: Censo de 1940. Elaboração do autor.

Gráfico 1 - Principais posições no mercado de trabalho no Brasil em 1940 (em números absolutos)

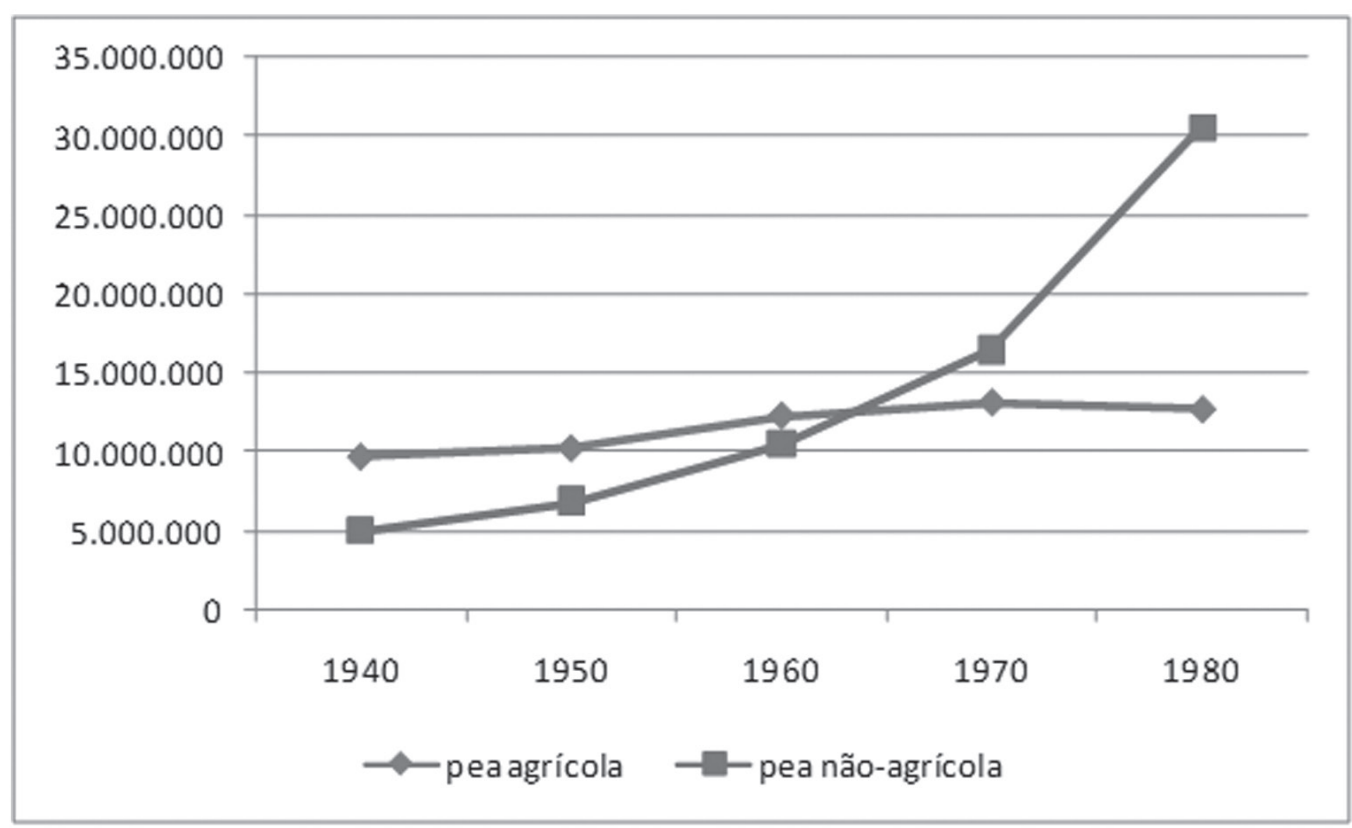

Fonte: Censos Demográficos. Elaboração do autor.

Gráfico 2 - Evolução da PEA agrícola e não agrícola no Brasil, 1940 a 1980 (em números absolutos) 


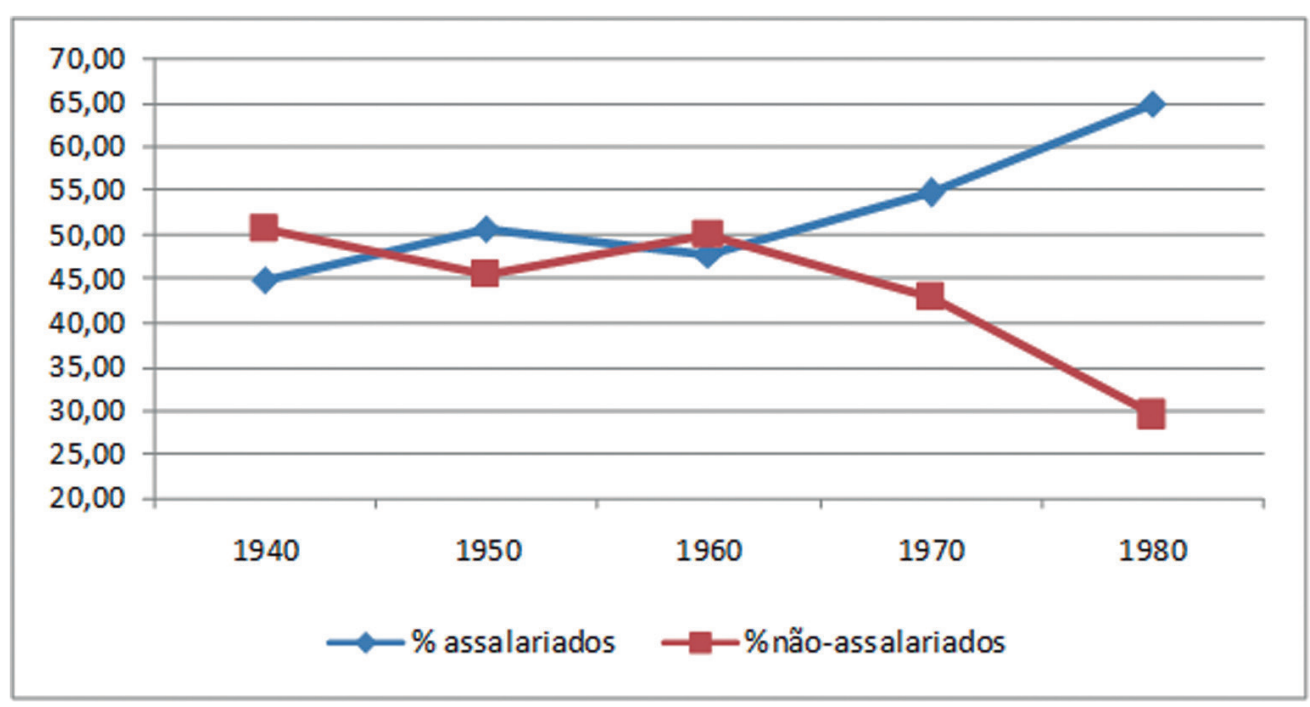

Fonte: Censos Demográficos. Elaboração do autor.

Gráfico 3 - Participação dos assalariados (com e sem carteira) e dos não assalariados (soma dos autônomos e do grupo "membros da família”) no total de ocupados no Brasil, 1940 a 1980 (em \%)

Em segundo lugar, importa enfatizar a regulamentação seletiva do fator trabalho e o vulto dos segmentos não assalariados. Observa-se, por exemplo, que o salto da taxa de assalariamento se dá apenas nos anos 1960 e, especialmente, nos anos 1970, quando chega a 65\% dos trabalhadores ocupados em 1980, contra 45\% em 1940 (Gráfico 3). Isso significa que, ao longo de todo o período, os trabalhadores assalariados - com e sem carteira - crescem 4,2 vezes, chegando a um total de 28 milhões em 1980. A participação dos não assalariados cai para cerca de $30 \%$ dos ocupados, mas com diferenças importantes entre as áreas rurais e urbanas. Ainda assim, o seu contingente cresce 70\%, em termos absolutos, no período 1940-1980.

A Tabela 2 apresenta os dados da PNAD 1976, que servem como uma síntese do final do processo de consolidação e nacionalização do mercado de trabalho. A média brasileira ainda é muito influenciada pela dinâmica do Brasil rural, onde as relações de trabalho caminhavam paulatinamente para uma feição mais capitalista, transformando o roceiro em boia-fria. Ainda assim, em 1976, apenas um terço dos trabalhadores do Brasil rural eram assalariados, e a cada três assalariados, dois não possuíam carteira de trabalho.

Mas, mesmo no Brasil urbano, 35\% dos assalariados não possuíam carteira de trabalho assinada, enquanto $20 \%$ do total dos ocupados eram não assalariados. Esse quadro, aliás, não era significativamente diverso na Região Metropolitana de São Paulo, posto mais avançado do mercado de trabalho nacional, e onde havia maior diversificação social, levando a ocupações típicas da classe 
média assalariada; mas também a uma precarização de tipo diverso, associada aos baixos salários, longas jornadas de trabalho e altos custos de subsistência, especialmente com transporte e moradia, num contexto de extensas jornadas de deslocamento e de crescente favelização urbana.

Tabela 2 - Posições na ocupação em relação ao total de ocupados no Brasil, 1976 (números absolutos e \%)

\begin{tabular}{l|c|c|c|c}
\hline \multirow{2}{*}{ Brasil rural } & $\begin{array}{c}\text { Assalariado com } \\
\text { carteira }\end{array}$ & $\begin{array}{c}\text { Assalariado sem } \\
\text { carteira }\end{array}$ & Não assalariados & Total $^{*}$ \\
\cline { 2 - 5 } & 1.633 .525 & 3.207 .947 & 8.866 .712 & 13.708 .184 \\
\hline \multirow{2}{*}{ Brasil urbano } & $11,9 \%$ & $23,4 \%$ & $64,7 \%$ & $100,0 \%$ \\
\cline { 2 - 5 } & 12.465 .900 & 6.505 .447 & 4.874 .972 & 23.846 .319 \\
\hline \multirow{2}{*}{ Brasil } & $52,3 \%$ & $27,3 \%$ & $20,4 \%$ & $100,0 \%$ \\
\hline \multirow{2}{*}{ RMSP } & 14.098 .815 & 10.358 .852 & 13.742 .010 & 38.199 .677 \\
\cline { 2 - 5 } & $36,9 \%$ & $27,1 \%$ & $36,0 \%$ & $100,0 \%$ \\
\cline { 2 - 5 } & 2.507 .485 & 1.049 .579 & 881.450 & 4.438 .514 \\
\hline
\end{tabular}

Fonte: PNAD 1976. Elaboração do autor.

* não estão incluídos no total os empregadores.

Em terceiro lugar, a desigualdade de rendimentos era uma marca dentro e fora do mercado de trabalho. Dentro, pois havia uma expressiva desigualdade de salários entre os trabalhadores com carteira e os sem carteira. E também porque havia uma elevada concentração de trabalhadores não assalariados com níveis de renda próximos aos valores mais baixos obtidos pelos assalariados.

Esse subproletariado - que conforma o conjunto de trabalhadores que não logram obter a "reprodução normal" da sua força de trabalho, ou por serem "superexplorados" (ganham menos do que o salário mínimo), ou por se "autoexplorarem", na medida em que são obrigados (no caso dos autônomos) a ofertar produtos em mercados saturados - chegaria a representar $53 \%$ dos ocupados nas atividades não agrícolas e $84 \%$ nas atividades agrícolas (Singer, 1981, p.104-6, 129). A diferenciação desse segmento, com relação ao "proletariado propriamente dito", não remete a uma divisão estanque, já que um mesmo trabalhador podia sair e entrar facilmente dos dois grupos.

Em 1980, um terço dos autônomos possuía renda média muito próxima à dos analfabetos assalariados. Se a renda média dos autônomos era, em média, $20 \%$ maior do que a dos assalariados, isso se devia ao fato de que, primeiro, a renda dos assalariados sem carteira jogava a renda média desse grupo para baixo; mas também porque havia maior dispersão dos seus rendimentos em relação aos assalariados em geral. Nas faixas de maior escolaridade, a renda dos autônomos - aqui, na prática, atuando como empreendedores quase-capitalistas - superava a dos assalariados. Nesse sentido, a desigualdade de rendimentos entre os conta 
própria é um reflexo das desigualdades salariais presentes no núcleo capitalista (Prandi, 1980, p.139, 149-52). Como o salário é rebaixado nesse setor - por conta da rotatividade, da repressão sindical e da política de salário mínimo -, a renda dos autônomos - alfaiates, mecânicos, manicures, costureiras, marceneiros, pedreiros e vendedores ambulantes - que produzem para a classe trabalhadora também o é. O oposto acontece com os segmentos que fornecem bens e serviços qualificados para as empresas capitalistas.

Paralelamente, o trabalhador médio da indústria recebia uma renda quase três vezes superior ao trabalhador agrícola, ao passo que o trabalhador dos serviços de utilidade pública ganhava o dobro do trabalhador na construção civil, ocupação caracterizada pela elevada presença de empregados sem carteira. $\mathrm{O}$ trabalhador de serviços pessoais nas áreas urbanas - geralmente autônomos - auferia, em 1980, uma renda que equivalia à cerca de metade do obtido pelo trabalhador agrícola. Esse quadro é ainda mais complexo nas metrópoles nordestinas, em virtude da "inusitada desproporcionalidade entre os que se empregam e os que permanecem desempregados ou em formas latentes do exército industrial de reserva", como no caso as atividades do segmento não capitalista (Oliveira, 1980, p.13-14).

Em quarto lugar, o desigual acesso às políticas sociais aprofundava a segmentação espacial e setorial do mercado de trabalho. Isso fica evidente no acesso à previdência social, onde apenas algumas ocupações assalariadas são contempladas, comprometendo severamente o acesso à saúde dos assalariados sem carteira e autônomos.

No caso da educação, o Gráfico 4 aponta para uma estabilidade inquietante: $60 \%$ dos trabalhadores ocupados não haviam concluído o ensino fundamental no período de 1960 a 1980 . A mudança fica a cargo da redução do percentual de analfabetos, de $32 \%$ para $16 \%$, a longo do período. E para o aumento daqueles que possuíam secundário ou superior completo, cujo percentual em relação aos ocupados salta de $5 \%$ para $16,5 \%$.

Ao contrário do que sugere a teoria do capital humano, a forte elevação da desigualdade na renda do trabalho, entre 1960 e 1980, não estava relacionada à relação entre oferta e demanda para cada faixa educacional. Mas ao fato de que novos postos intermediários foram criados para a classe média assalariada emergente em virtude do próprio processo de diversificação da economia capitalista. Essa se localizava tanto no setor público como no privado, além de possuir algum diploma e acesso às políticas sociais. A depressão da renda da classe trabalhadora em termos relativos era assegurada por um conjunto de políticas restritivas, mas também à dinâmica de um mercado com excedente estrutural de força de trabalho. 


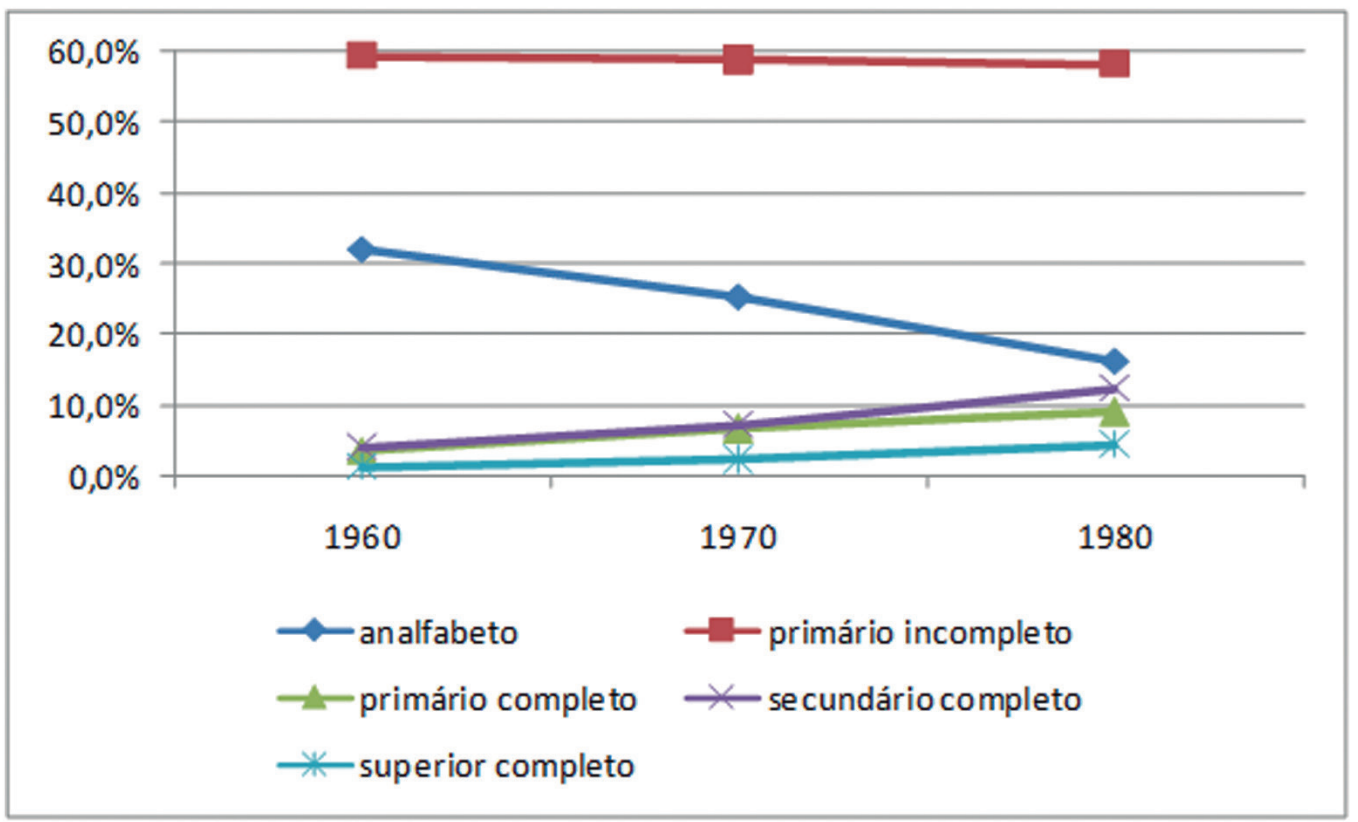

Fonte: Censos demográficos. Elaboração do autor.

Gráfico 4 - Distribuição dos ocupados por grau de escolaridade no Brasil, 1960 a $1980(\mathrm{em} \%)$

Como resultado desse mercado de trabalho heterogêneo e desigual, a estrutura social brasileira, ao final do processo de consolidação do capitalismo, possuiria uma feição marcadamente original.

No estrato superior, uma classe alta urbana e rural, formada por um patronato de empresários e proprietários e por um patriciado localizado nos cargos públicos, ao qual se agregaria o segmento gerencial de empresas públicas e privadas, gerando uma nova classe média, que se diferenciava de outro estrato intermediário conformado pelos profissionais liberais e funcionários públicos em geral.

Abaixo se situava a classe baixa urbana formada pelo operariado e pelos empregados de lojas e escritórios, os quais acreditavam nas perspectivas da mobilidade social. Esse grupo se diferenciava “classe dependente urbana”, conformada pelos assalariados eventuais e autônomos de baixa renda, que coincide com o "subproletariado" de Paul Singer, ou com o conceito de ralé, recentemente desenvolvido por Souza (2003, p.153-61) para caracterizar os segmentos de "desclassificados sociais", para os quais as noções de dignidade no trabalho e cidadania (acesso a políticas sociais) encontram-se vedadas.

A gênese desse segmento social encontra-se no processo de transformação dos escravos e agregados de ontem em subassalariados de hoje, conforme explicita Ribeiro (1995, p.210-11). Tal processo refletiu não meramente a transmissão de uma herança do passado, mas uma redefinição das posições de classe 
no âmbito de um capitalismo subdesenvolvido e dependente, incapaz de lograr a universalização de um estatuto coletivo do trabalho. Falta agregar a essa classificação geral, esboçada por Fernandes (1975, p.59-65), o camponês, "classe por-vir-a-ser", em virtude do acesso limitado à propriedade de terra, oscilando entre um operariado rural emergente e uma classe dependente rural em processo de expropriação.

Essa estratificação social profundamente hierárquica e complexa foi engendrada não apenas pela dinâmica do mercado de trabalho, mas também pelos privilégios assegurados ao processo de acumulação de capital, especialmente por parte do Estado, que quando acionou políticas sociais, ou de "equidade", o fez no sentido de ampliar o fosso criado pela dinâmica do mundo do trabalho (Santos, 1998, p.106-9). A ação de duplo condicionamento entre mercado de trabalho e estrutura social confere uma chave explicativa para a dificuldade de se levar a cabo alterações estruturais da distribuição de poder e da renda nesta modalidade de capitalismo.

\section{Considerações finais}

Os historiadores, com alguma razão, preferem guardar distância de análises envolvendo longos períodos. Os sociólogos e economistas já não têm tantas precauções, mas por vezes partem de modelos que desconsideram o processo histórico na sua complexidade.

O presente ensaio procurou realizar uma síntese das principais transformações ocorridas no mundo do trabalho no Brasil desde a colônia até o final do processo de industrialização. Para fazê-lo optamos por estabelecer alguns cortes transversais no tempo. Portanto, mais que contar essa história, buscamos apontar os nexos estruturais presentes nos três períodos decisivos para a formação do mercado de trabalho no Brasil. Seguindo os ensinamentos de Braudel, para além das descontinuidades, focamos nas continuidades impostas pelo passivo colonial, e sempre remodeladas, de acordo com o padrão de desenvolvimento.

Como foi possível, partindo da colônia com seus escravos e homens livres pobres, construir as condições para a operacionalização de um mercado de trabalho peculiar no pós-1930? Qual o papel do Estado, das diferenças regionais e do comportamento das elites econômicas durante a transição entre 1850 e 1930? Que tipos de relações de trabalho predominaram em cada período para os principais segmentos da força de trabalho? Como a inserção diferenciada no mundo de trabalho se articulou a padrões distintos de estratificação social? E mais, como a plena conformação de um processo endógeno de acumulação de capital, entre 1930 e 1980, moldou um mercado de trabalho heterogêneo, setorial e espacialmente, mas também em termos dos vários tipos de inserção no mundo do trabalho e na sociedade? 
Essas perguntas são relevantes, pois não estava dado de antemão que, no mesmo território onde vicejou a colônia dos séculos XVII e XVIII, seria possível gerar uma oferta elástica de mão de obra capaz de satisfazer a expansão interna do segmento capitalista ao longo do século XX, mas também de um segmento não capitalista a ele articulado e subordinado.

A dinâmica internacional, a mudança da estrutura da economia brasileira, a atuação do Estado e as coalizões de classe que predominaram no século XX contribuem para explicar a consolidação e nacionalização do mercado de trabalho no Brasil, mas apenas se levarmos em consideração que esse processo não se deu num vácuo histórico.

Por usa vez, a expansão do capitalismo agravaria a heterogeneidade estrutural. Pois se faria acompanhar de uma profunda desigualdade entre as várias frações de capital e as várias posições de classe dos que vivem do trabalho: classe média assalariada, operários com acesso aos direitos básicos do trabalho, operários precários, além de um amplo segmento formado pelo subproletariado, classe dependente urbana ou ralé, conforme a definição.

Enfim, um mercado de trabalho que se modernizou, mas ampliando o seu caráter excludente e concentrador, bem ao estilo do capitalismo subdesenvolvido e dependente; além de qualitativamente diverso das sociedades salariais dos países desenvolvidos, onde se logrou instaurar um estatuto coletivo do trabalho, ao menos até 1980.

É importante ressaltar, contudo, que esse esforço de periodização e generalização não se detém nas clivagens do mundo do trabalho em termos de raça/ cor, gênero, rural/urbano e regionais, sem as quais não se pode chegar a uma compreensão aprofundada e mais precisa da dinâmica social e econômica em cada momento. Esperamos que o sentido da totalidade, aqui esboçado, possa fornecer instrumentos e pistas para futuros estudos de natureza historiográfica.

\section{Referências}

ALENCASTO, L. F. O trato dos viventes: formação do Brasil no Atlântico Sul. São Paulo: Cia. das Letras, 2000.

BARBOSA, A. F. A formação do mercado de trabalho no Brasil. São Paulo: Alameda, 2008.

CUNHA, M. C. Negros, estrangeiros: os escravos libertos e sua volta à África. 2.ed. São Paulo: Cia. das Letras, 2012.

FERNANDES, F. Sociedade de classes e subdesenvolvimento. 3.ed. Rio de Janeiro: Zahar, 1975.

A revolução burguesa no Brasil. 3.ed. Rio de Janeiro: Guanabara, 1987.

FURTADO, C. Formação econômica do Brasil. São Paulo: Fundo de Cultura, 1959.

HASENBALG, C. Discriminação e desigualdades raciais no Brasil. 2.ed. Belo Horizonte: Editora UFMG, 2005. 
MARX, K. Formações econômicas pré-capitalistas. 6.ed. São Paulo: Paz e Terra, 1991.

MATTOSO, K. Ser escravo no Brasil. 3.ed. São Paulo: Brasiliense, 1990.

MELLO, E. C. O Norte agrário e o Império, 1871-1889. 2.ed. Rio de Janeiro: Topbooks, 1999.

MELLO E SOUZA, L. Desclassificados do ouro: a pobreza mineira no século XVIII. 4.ed. São Paulo: Graal, 2004.

OLIVEIRA, F. Salvador: os exilados da opulência (expansão capitalista numa metrópole pobre). In: FARIA, V. et al. Babia de Todos os Pobres. Petrópolis: Vozes, 1980.

PRADO JUNIOR, C. Formação do Brasil contemporâneo. São Paulo: Martins, 1942.

História econômica do Brasil. 32.ed. São Paulo: Brasiliense, 1985.

PRANDI, J. R. Trabalhadores por conta própria em Salvador. In: FARIA, V. et al. Babia de Todos os Pobres. Petrópolis: Vozes, 1980.

RANGEL, I. Introdução ao desenvolvimento econômico brasileiro. Salvador: Progresso, 1957.

RIBEIRO, D. O povo brasileiro: a formação e o sentido do Brasil. São Paulo: Cia. das Letras, 1995.

SANTOS, W. G. Décadas de espanto e uma apologia democrática. Rio de Janeiro: Rocco, 1998.

SCHWARTZ, S. Segredos internos: engenhos e escravos na sociedade colonial. São Paulo: Cia. das Letras, 1995.

SINGER, P. Dominação e desigualdade: estrutura de classes e repartição da renda no Brasil. Rio de Janeiro: Paz e Terra, 1981.

SOARES, L. C. O povo de "Cam" na capital do Brasil: a escravidão urbana no Rio de Janeiro do século XIX. Rio de Janeiro: Faperj/7 Letras, 2007.

SOUZA, J. A construção social da subcidadania: para uma sociologia política da modernidade periférica. Belo Horizonte: Editora UFMG, 2003.

WEBER, M. Historia económica general. México: Fondo de Cultura Económica, 2001.

RESUMO - O presente artigo tem por objetivo traçar as características gerais do processo de formação do mercado de trabalho no Brasil. Três períodos são priorizados: colônia; a transição de 1850 a 1930; e a nacionalização do mercado de trabalho (1930 a 1980). Os elementos estruturais de cada período são esmiuçados. Dessa forma, procura-se apontar para os elementos de continuidade e descontinuidade que darão sentido ao mercado de trabalho no Brasil durante a consolidação do capitalismo. O resultado é um mercado de trabalho heterogêneo, com altas taxas de assalariamento, mas também caracterizado pela precarização sob várias formas, gerando uma sociedade desigual, mas num sentido completamente diferente do verificado nos períodos anteriores. Ainda assim, o peso da história é uma presença ativa nessa sociedade capitalista, moderna e excludente.

PALAVRAS-CHAVE: Mercado de trabalho, Escravidão, Assalariamento, Desigualdade, Capitalismo. 
ABSTRACT - This article outlines the general characteristics underpinning the development of the labor market in Brazil. Three periods are focused: colonial, transition from 1850 to 1930 , and nationalization of the labor market (1930 to 1980). The structural components of each period are scrutinized and we focus on the interaction between continuity and discontinuity in the labor market during the consolidation of capitalism in Brazil. The result has been a heterogeneous labor market, with a high proportion of wage earners, but also characterized by various forms of precariousness and informality that paved the way for an unequal society, albeit in a completely different sense than that observed in other periods of Brazilian history. Nevertheless, the weight of history should not be neglected in this capitalist, modern and exclusionary society.

KEYWORDS: Labor market, Slavery, Wage earners, Inequality, Capitalism.

Alexandre de Freitas Barbosa é professor de História Econômica e Economia Brasileira do Instituto de Estudos Brasileiros da Universidade de São Paulo (IEB/USP).

@ - afbarbosa@usp.br

Recebido em 24.6.2016 e aceito em 5.7.2016.

I Instituto de Estudos Brasileiros, Universidade de São Paulo, São Paulo/ São Paulo, Brasil. 